\title{
ATMOSPHERIC MERCURY MEASUREMENTS \\ AT CAPE POINT, SOUTH AFRICA
}

\author{
Ernst-G. Brunke ${ }^{* 1}$, Casper Labuschagne ${ }^{1}$, Franz Slemr ${ }^{2}$, Ralf Ebinghaus ${ }^{3}$ \\ and Hans Kock ${ }^{3}$. \\ ${ }^{1}$ South African Weather Service, Jan Cilliers Street, Stellenbosch, 7599, South Africa, \\ ernst.brunke@weathersa.co.za \\ ${ }^{2}$ Max-Planck Institute for Chemistry, Atmospheric Chemistry Division, P.O. Box 3060, 55020 Mainz, Germany, \\ franz.slemr@mpic.de \\ ${ }^{3}$ GKSS Research Centre, Institute for Coastal Research, 21502 Geesthacht, Germany, \\ ralf.ebinghaus@gkss.de
}

\begin{abstract}
Over the 1995-2009 period the gaseous elemental mercury (GEM) concentrations have decreased by about $0.04 \mathrm{ng} \mathrm{m}^{-3} \mathrm{yr}^{-1}$.at Cape Point (CPT). A reduction of the same magnitude is indicated by measurements during intermittent ship cruises, implying a homogeneous distribution of GEM concentrations in the Southern Hemisphere $(\mathrm{SH})$ and a $30 \%$ reduction of its atmospheric burden. Almost all GEM measurements in the Northern Hemisphere $(\mathrm{NH})$ point to a substantial decrease but the trends are inhomogeneous, most likely due to a variable source distribution. However, measurements in the $\mathrm{NH}$ during ship cruises suggest a trend of similar magnitude. A decrease in the total atmospheric GEM burden by about $30 \%$ is inconsistent with the current mercury budgets. The most probable explanation for this is subsiding re-emissions from the legacy of large past emissions.

High-resolution data since 2007 revealed depletion (DEs) as well as pollution events (PEs). Both types are embedded in air masses ranging from marine background to continental. The DEs observed at Cape Point are a local phenomenon $(<100 \mathrm{~km})$ and are the first mercury depletion events reported outside the Polar Regions. In contrast to polar DEs, the DEs at CPT are not accompanied by concurrent $\mathrm{O}_{3}$ depletion. They mostly appear at wind speeds $<10 \mathrm{~m} \mathrm{~s}^{-1}$ and their predominating occurrence between 11 and 18 hours suggests a photochemical destruction mechanism which could not be explained yet.

GEM correlates with $\mathrm{CO}, \mathrm{CO}_{2}$, and $\mathrm{CH}_{4}$ during most PEs at CPT (GEM levels $>1.3 \mathrm{ng} \mathrm{m}^{-3}$ ) and with ${ }^{222} \mathrm{Rn}$ during about half the events. Most of the observed GEM/CO emission ratios are within the range bracketed by values reported for biomass burning and industrial/urban emissions, thus suggesting a mixture of both. No significant differences of GEM/CO and $\mathrm{GEM} / \mathrm{CO}_{2}$ could be found between different source regions defined by backward trajectories. This implies that exceptionally high emissions ascribed to the Gauteng region in global mercury inventories are overestimated.
\end{abstract}

Keywords: Gaseous elemental mercury (GEM); seasonal cycle; trends; depletion and pollution events.

\section{Introduction}

Mercury is a bio-accumulative, toxic metal, which is emitted from both natural and anthropogenic sources into the atmosphere (Schroeder and
Munthe 1998). It typically occurs in the atmosphere in three possible states: gaseous elemental mercury (GEM), gaseous divalent mercury $\left(\mathrm{Hg}^{2+}\right)$, and particulate mercury $\left(\mathrm{Hg}_{(\mathrm{p})}\right)$. GEM, which makes up more than $98 \%$ of these 
species (Wängberg et al. 2008) has been measured at CPT since 1995 (Baker et al. 2002). The first ten years of measurements were made manually using an atomic fluorescence spectroscopic (AFS) analyser, with the monthly sampling frequency fluctuating between 2 and 27. Since March 2007, however, a Tekran 2537A vapour -phase mercury analyser (Tekran Inc., Toronto, Canada) has been used, which enabled measurements to be made once every 15 minutes. This high-resolution data set revealed depletion and pollution events (Brunke et al. 2010) not previously observed in the older, lower frequency data set. In this paper we will summarize previous results (Baker et al. 2002, Brunke et al. 2001, Slemr et al. 2008 and Brunke et al. 2010), focussing on seasonal cycles, long-term trends, depletion and pollution events.

\section{Seasonal Cycles}

The composite annual data from September 1995 till June 1999 (low temporal resolution of about 200 samples per year) showed maximum concentrations during January - February (summer) and minima during austral winter (Slemr et al. 2008). The high resolution data collected from April 2007 till the end of 2009 in turn - have also been analysed for their seasonality. An important feature is that the individual years (2007, 08 and 09) are not very consistent with regard to their seasonal cycles. Nonetheless, the overall tendency of the unfiltered data indicates autumn maxima and spring minima (Figure 1). All-in-all the seasonal GEM cycle is not so clearly defined, but if anything, it is out of phase to that of $\mathrm{CO}$, whilst in the Northern Hemisphere $(\mathrm{NH})$ it is in phase. The inter-annual differences of CPT GEM levels suggest that variable and less stable processes are driving the annual $\mathrm{Hg}$ variations in the Southern Hemisphere (SH) compared to the $\mathrm{NH}$. This probably includes: biomass burning, import from the $\mathrm{NH}$ into the $\mathrm{SH}$ and oxidation via $\mathrm{OH}$ in the $\mathrm{NH}$ as well as oceanic emissions. Such oceanic $\mathrm{Hg}$ sources may be of greater quantitative significance in the $\mathrm{SH}$ than they are in the NH (Slemr et al. 2008).

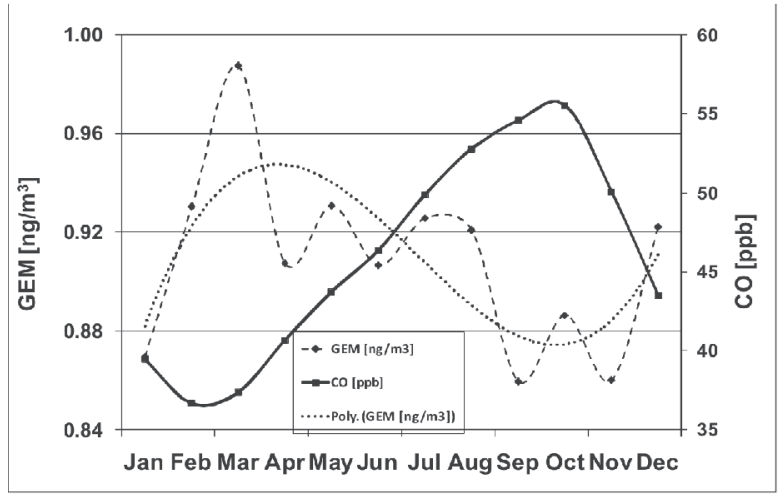

Figure 1: Composite seasonal cycles $(2007$ - 2009) for GEM and CO.

\section{Long-term trends}

Due to human health considerations (Mergeler et al. 2007), measures have been introduced in many parts of the world to curb mercury emissions. On the other hand, emissions in developing countries may have been increasing. Nonetheless, the overall GEM trend as measured at CPT (Figure 2) over the 1995 2009 period has decreased at a rate of about $0.04 \mathrm{ng} \mathrm{m}^{-3} \mathrm{yr}^{-1}$. To the best of our knowledge, no other long-term GEM time series has been reported for the $\mathrm{SH}$, which could serve for comparison.

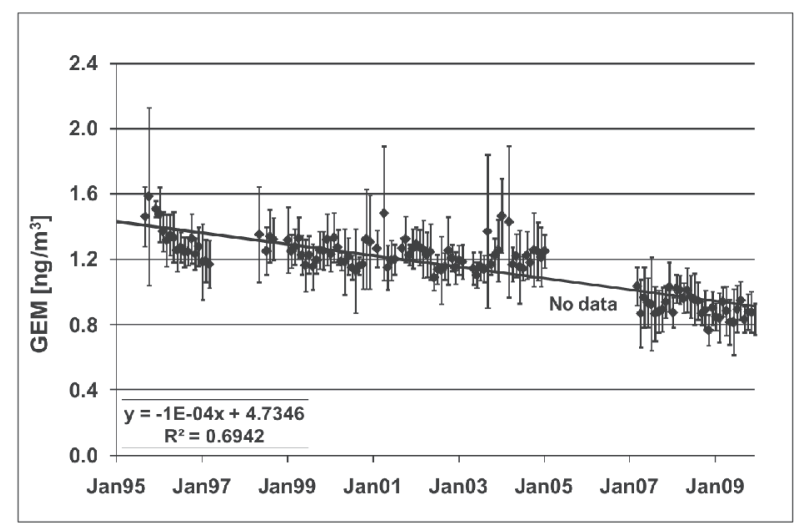

Figure 2: GEM time series (1995 - 2009): monthly means with standard deviations as error bars.

GEM measurements from ship cruises (Temme et al. 2003) in both hemispheres and at Mace Head, Ireland, NH (Ebinghaus et al. 2001) also indicate a long-term $\mathrm{Hg}$ decline. The observed overall global decrease implies a GEM reduction of $30 \%$ within the atmosphere. This is quite considerable and inconsistent with the current $\mathrm{Hg}$ budget (Selin et al. 2007). A significant shift in the biogeochemical cycle of $\mathrm{Hg}$, possibly involving oceanic (Mason and Sheu 2002) and soil sources, is indicated. Anthropogenic emissions including biomass burning per se (Streets et al., 2009; Pacyna et al., 2010), can, however, not adequately explain the observed decrease, because only $1 / 3$ of the $\mathrm{Hg}$ source is attributed to direct human activities (Selin et al. 2007). Another possibility might be enhanced $\mathrm{Hg}$ removal via its reactions with $\mathrm{OH}$, $\mathrm{O}_{3}$ and $\mathrm{Br} / \mathrm{BrO}$. However, there are no indications that these three gaseous species have increased markedly over the past ten years to account for this. An increase of the $\mathrm{OH}$ level - the primary cleansing agent of atmospheric trace gas species (Thompson A.M. 1992) - would have had an influence on other atmospheric trace gases such $\mathrm{CH}_{4}$ as well - and this has not been observed yet. In fact, $\mathrm{CH}_{4}$ has increased world-wide (Rigby et al. 2008). At CPT an increase of $0.9 \%$ has been observed over the past three years (2007 - 2009) with respect to the 2003 - 2006 average (1730.3 
ppb). GEM is also removed from the atmosphere via reactions with $\mathrm{O}_{3}$ and $\mathrm{Br} / \mathrm{BrO}$. In both these cases, there is also no evidence that $\mathrm{Br} / \mathrm{BrO}$ (WMO 2007) and $\mathrm{O}_{3}$ (Oltmans et al. 2006) have increased to such a degree as to account for the observed GEM decline.

We speculate that the observed decrease in the atmospheric GEM burden can be attributed to declining atmospheric emissions from soil and oceanic reservoirs that have in the past been fed by anthropogenic emissions. The phasing out of industrial $\mathrm{Hg}$ processes and $\mathrm{Hg}$ containing products (Hylander and Meili 2005), which commenced in the late 1980s, as well as the declining emissions from coal burning since the late 1970s and 1980s has reduced the inputs to these reservoirs. We hence attribute the declining GEM trend to reduced emissions from these classical reservoirs.

\section{Depletion events}

The high resolution (15 min averages) GEM data has revealed depletion events (DEs) in the CPT record (2007 - 2009), which were not previously seen (Brunke et al. 2010). During such events, GEM levels often decreased from about $1 \mathrm{ng} \mathrm{m}$ ${ }^{3}$ to $<0.20 \mathrm{ng} \mathrm{m}^{-3}$ (Figure 3 ).

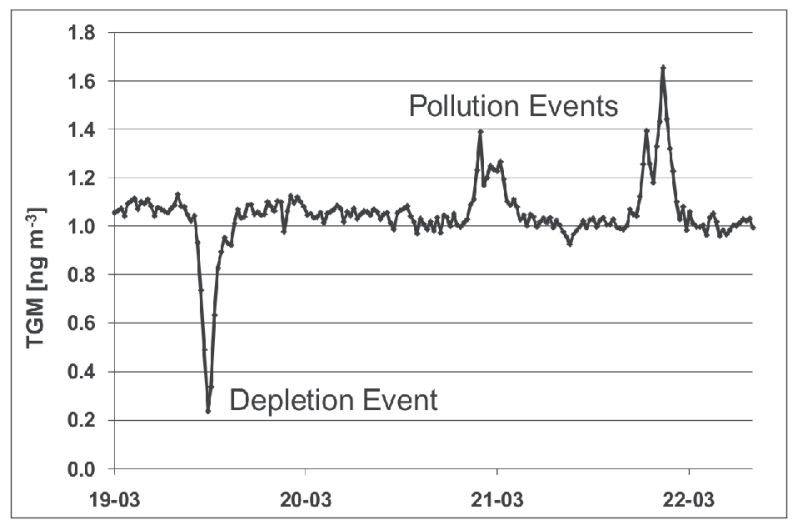

Figure 3: Extract of CPT GEM time series (19 - 22 March 2007) showing DE and PEs.

DEs have been observed at CPT under different conditions of air advection - varying from clean maritime to continental and urban (anthropogenic). This has been substantiated by corresponding ${ }^{222} \mathrm{Rn}, \mathrm{CO}$ and $\mathrm{O}_{3}$ levels as well as by isentropic back-trajectories. $\mathrm{CO}$, in particular, is a very sensitive indicator for urban pollution, while ${ }^{222} \mathrm{Rn}$ is a powerful tracer allowing marine and continental air to be distinguished from each other (Brunke et al. 2002). The DEs detected are independent of wind direction, but they almost exclusively take place at wind velocities $<10 \mathrm{~m} \mathrm{~s}^{-1}$. Furthermore, they are mainly observed during the afternoon from 11:00 to $18: 00$ suggesting that some kind of photochemical reactions of as yet unknown mechanism are involved here. The three years of data collected to date does not indicate a significant seasonal preference or typical annual frequency for DEs. During 2009, 89\% more DEs were recorded than during 2008.

To the best of our knowledge, mercury depletion events have - with a few exceptions - only been reported for the Polar Regions. The CPT type DE constitutes a new phenomenon with its own characteristics, which differ from the polar atmospheric depletion events (ADMEs) in several respects. At CPT, DEs have been observed during all seasons, while the polar ADMEs occur during spring and early summer and are associated with high levels of $\mathrm{BrO}$ concentrations (Steffen et al. 2008). In addition, CPT events are shorter and not accompanied by concurrent $\mathrm{O}_{3}$ reductions as are the polar ADMEs (Schroeder et al. 1998, Ebinghaus et al. 2002). They constitute local processes within a radius of about $100 \mathrm{~km}$. Additional work is, however, required to elucidate the mechanism of the CPT type DE. The vegetation in the Cape Peninsula and coastal kelp beds might constitute a source of volatile organic compounds (VOCs), which in combination with marine halogens could be involved in GEM depletion reactions without significantly affecting surface $\mathrm{O}_{3}$ (Brunke et al. 2010). Consequently, VOC measurements as well as the identification of the mercury species involved should assist in elucidating the underlying chemical mechanisms of GEM depletion.

\section{Pollution events}

Besides DEs, pollution events (PEs) are at times also recorded at CPT. These are generally observed in the northern wind sector (Brunke et al. 2010) and unlike the DEs occur almost exclusively in polluted air masses, which are characterized by elevated levels of $\mathrm{CO}, \mathrm{CO}_{2}$ as well as ${ }^{222} \mathrm{Rn}$. Ozone levels during PEs show a large range of variability. They are sometimes elevated ( $>50 \mathrm{ppb}$ ) due to photochemical production or depleted (nocturnal titration via NO) thereby reaching levels of $<10 \mathrm{ppb}$. Events have been arbitrarily classified as PE when their GEM concentrations $>1.3 \mathrm{ng} \mathrm{m}^{-3}$ were lasting for two or more hours. Based on this cut off, 84 PEs have been found during the period from March 2008 till October 2009. These often last for a few hours and are attributed to anthropogenic activities such as medical waste incineration, landfills and coal burning (Pacyna et al. 2006). Using isentropic back trajectories from NOAA-ESRL (http://www.esrl.noaa gov/gmd) these PEs have been broadly classified into three general fetch regions, i.e. those which originate locally (Cape Town), regionally (Cape Province), and those that are derived from within the sub-continent (e.g. Gauteng, Zimbabwe, Malawi). The GEM sources from the greater Cape Town region 
constitute primarily medical waste incineration, while the up-country sources (e.g. Gauteng) comprise essentially coal-fired power stations. Gold extracting techniques practiced in certain sub-Saharan countries (e.g. Malawi and Zimbabwe) are also contributors. However, the overriding primary GEM source for Southern Africa, may be biomass burning.

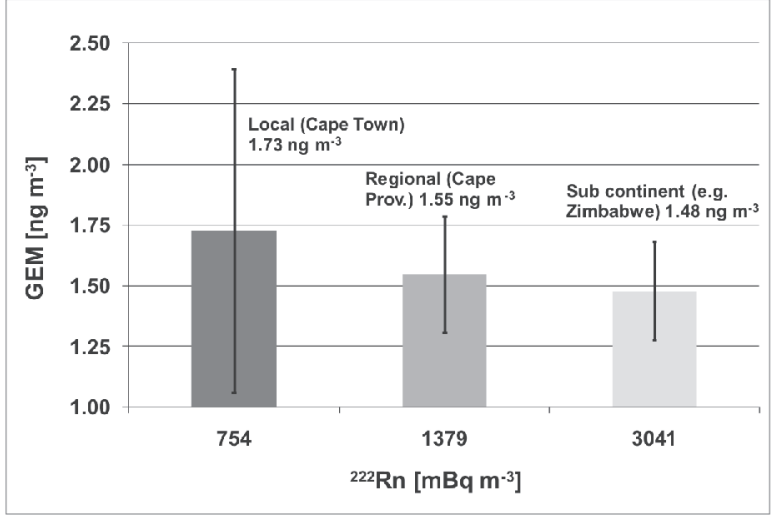

Figure 4: Average GEM and ${ }^{222} \mathrm{Rn}$ levels for three fetch regions, respectively, which only vary marginally with respect to GEM (ng m ${ }^{-3}$ ): Cape Town (1.73); Cape Province (1.55) and sub-continental (1.48). The average ${ }^{222} \mathrm{Rn}$ levels $\left(\mathrm{mBq} \mathrm{m}^{-3}\right)$, in turn, have a larger range varying from 754 (Cape Town) to 1379 (Cape Province) to transport from up country (3041). This is in accordance with the progressively longer continental exposure times of these air masses.

$\mathrm{GEM} / \mathrm{CO}$ and $\mathrm{GEM} / \mathrm{CO}_{2}$ ratios have been determined for the various PEs in an attempt to classify these either as anthropogenic or as a result of biomass burning (Ebinghaus et al. 2005).

Most of the observed GEM/CO emission ratios fall within the range bracketed by values reported for biomass burning $\left(\sim 1.5 \mathrm{ng} \mathrm{m}^{-3} \mathrm{ppb}^{-}\right.$ $\left.{ }^{1}\right)$ and industrial/urban emissions ( $\sim 6 \mathrm{ng} \mathrm{m}^{-3}$ $\mathrm{ppb}^{-1}$ ) (Slemr et al. 2009), thus suggesting a mixture of both. However, no significant differences of GEM/CO and GEM/CO ${ }_{2}$ could be found between the three different source regions defined by backward trajectories. The average GEM levels are also very similar between the various regions. This suggests that the exceptionally high emissions ascribed to the Gauteng region in global mercury inventories (Pacyna et al. 2006) are somewhat overestimated. We in turn suggest that the observed, elevated GEM levels are largely derived from biomass burning within the subcontinent.

\section{Summary and conclusions}

Although a regular, repetitive annual cycle of GEM at CPT cannot be found for each year, the overall tendency does show an autumn maximum and a spring minimum. This is out of phase to that of $\mathrm{CO}$ suggesting that $\mathrm{OH}$ is not the primary driver of the GEM annual curve as it is in the $\mathrm{NH}$. Other sources could be more prominent in the $\mathrm{SH}$ such as oceanic emissions and biomass burning, which leave their mark on the seasonal cycle.

The GEM trend at CPT shows an overall decrease of $0.04 \mathrm{ng} \mathrm{m}^{-3} \mathrm{yr}^{-1}$ for the 1995 to 2009 measuring period. This constitutes a decline of about $30 \%$, which is considerable. We propose that the declining atmospheric GEM levels might be due to dwindling anthropogenic emissions and associated lower emissions from soil and oceanic reservoirs.

GEM DEs - previously only reported for the Polar Regions - have been seen at CPT within the high resolution data (2007 onwards). The characteristics of these events have been described in more detail by Brunke et al. 2010. However, so far no adequate explanation exists for the chemical mechanism of these events. The DEs are not a function of wind direction, although they occur generally at wind velocities $<10 \mathrm{~m} \mathrm{~s}^{-1}$. They also take place primarily from noon to late afternoon thereby implying some solar dependence for the reactions and so far do not show a seasonal preference.

In addition to DEs, PEs have also been observed occasionally at CPT. Isentropic back trajectories show that they can be attributed to anthropogenic emissions from the greater Cape Town area (e.g. medical waste incineration and landfills) as well as from the industrialized Gauteng - Mpumalanga region (coal-fired power stations) and other sub-continental sites, such as Zimbabwe and Malawi, where gold extraction procedures utilizing mercury are still being used in places. The GEM concentrations as well as GEM/CO and GEM/CO ${ }_{2}$ ratios do, however, only vary marginally between local, regional and sub-continental sites. It appears plausible that the major GEM source in subSaharan Africa is biomass burning.

\section{Acknowledgements}

We are most grateful to D. van der Spuy, B. Parker and T. Mkololo for having maintained the Tekran analyser at CPT in good shape.

\section{References}

Baker P.G.L., Brunke E-G., Slemr F. and Crouch A.M. 2002, 'Atmospheric mercury measurements at CPT, South Africa', Atmos. Environ. 36:2459-24565.

Brunke E-G., Labuschagne C. and Slemr F. 2001, 'Gaseous mercury emissions from a fire in the Cape Peninsula, South Africa, during January 2000', Geophys. Res. Lett. 28:1483-1486.

Brunke E-G., Labuschagne C., Parker B., van der Spuy D. and Whittlestone S. 2002, ' CPT GAW station ${ }^{222} \mathrm{Rn}$ detector: factors affecting sensitivity and accuracy', Atmos. Environ. 36:2257-2262. 
Brunke E-G., Labuschagne C., Ebinghaus R., Kock H. and Slemr F. 2010, 'Gaseous elemental mercury depletion events observed at Cape Point during 2007-08', Atmos. Chem. Phys. 10:1121-1131.

Dabrowski J.M., Ashton P.J., Murray K., Leaner J.J. and Mason R.P. 2008, 'Anthropogenic mercury emissions in South Africa: Coal combustion in power plants', Atmos. Environ. 42:6620-6626.

Ebinghaus R., Kock H.H., Coggins A.M., Spain T.G., Jennings S.G., Temme C. 2002, 'Long term measurements of atmospheric mercury at Mace Head, Irish west coast, between 1995 and 2001', Atmos. Environ. 36:5267-5276.

Ebinghaus R., Kock H.H., Temme C., Einax J.W., Löwe A.G., Richter A., Burrows, J.P. and Schroeder W.H. 2002, 'Antarctic springtime depletion of atmospheric mercury', Environ. Sci. Technol. 36:1238-1244.

Ebinghaus R., Slemr F., Brenninkmeijer C.A.M., Van Velthoven P., Zahn A., Hermann M., O'Sullivan D.A. and Oram D.E. 2007, 'Emissions of gaseous mercury from biomass burning in South America in 2005 observed during CARIBIC flights', Geophys. Res. Lett. 34:L08813, doi:10.1029/2006GL028866.

Hylander L.D. and Meili M. 2005, 'The rise and fall of mercury: Converting a resource to refuse after 500 years of mining and pollution', Crit. Rev. Environ Sci. Technol. 35:1-36.

Lin C.-J., Pongprueksa P., Lindberg S.E., Pehkonen S.O., Byun D. and Jang C. 2006, 'Scientific uncertainties in atmospheric mercury models I: Model science evaluation', Atmos. Environ. 40:2911-2928.

Mason R.P. and Sheu G. -R. 2002, 'Role of the ocean in the global mercury cycle', Global Biogeochem. Cycles 16:1093, doi:10.1029/2001GB001440.

Mergler D., Anderson H.A., Chan L.H.M., Mahaffey K.R., Murray M., Sakamoto M., Stern A.H. 2007, 'Methylmercury exposure and health effects in humans: A worldwide concern', Ambio 36:3-11.

Oltmans S.J., Lefohn A.S., Harris J.M., Galbally I., Scheel H.E., Bodeker G., Brunke E-G., Claude H., Tarasick D., Johnson B.J., Simmonds P., Shadwick D., Anlauf K., Hayden K., Schmidlin F., Fujimoto T., Akagi K., Meyer C., Nichol S., Davies J., Redondas A., Cuevas E. 2006, 'Long-term changes in tropospheric ozone', Atmos. Environ. 40:3156-3173.

Pacyna E.G., Pacyna J.M., Sttenhuisen F., Wilson S. 2006, 'Global anthropogenic mercury emission inventory for 2000', Atmos. Environ. 40:4048-4063.

Pacyna E.G., Pacyna J.M., Sundseth K., Munthe J., Kindbom K., Wilson S., Steenhuisen F., Maxson P. 2010, 'Global emissions of mercury to the atmosphere from anthropogenic sources in 2005 and projections to 2020', Atmos. Environ. 44:2487-2499.
Rigby et al. 2008, 'Renewed growth of atmospheric methane', Geophys. Res. Lett. 35:L22805, doi: 10.1029/2008GL036037.

Schroeder W.H. and Munthe J. 1998, 'Atmospheric mercury - an overview', Atmos. Environ. 32:809-822.

Selin N.E., Jacob D.J., Park R.J., Yantosca R.M., Strode S., Jaeglé L., Jaffe D. 2007, 'Chemical cycling and deposition of atmospheric mercury: Global constraints from observations', J. Geophys. Res. 112: D02308, doi:10.1029/2006JD007450.

Slemr F., Brunke E.-G., Labuschagne C. and Ebinghaus R. 2008, 'Total gaseous mercury concentrations at the Cape Point GAW station and their seasonality', Geophys. Res. Lett. 35:L11807, doi:10.1029/2008GL033741.

Slemr F., Ebinghaus R., Brenninkmeijer C.A.M., Herrmann M., Kock H.H., Martinsson B.G., Schuck T., Sprung D., van Velthoven P., Zahn A., Ziereis H. 2009, 'Gaseous mercury distribution in the upper troposphere and lower stratosphere observed onboard the CARIBIC passenger aircraft, Atmos. Chem. Phys. 9, 1957-1969.

Steffen A., Douglas T., Amyot M., Aryia P., Aspmo K., Berg T., Bottenheim J., Brooks S., Cobbett F., Dastoor A., Dommergue A., Ebinghaus R., Ferrari C., Gardfeldt K., Goodsite M.E., Lean D., Poulain A., Scherz C., Skov H., Sommar J., and Temme C. 2008, 'A synthesis of atmospheric mercury depletion event chemistry linking atmosphere, snow and water', Atmos. Chem. Phys. 8:1445-1482.

Streets D.G., Zhang Q., Wu Y. 2009 'Projections of global mercury emissions in 2050', Environ. Sci. Technol. 43, 2983-2988.

Temme C., Einax J.W., Ebinghaus R., Schroeder W.H. 2003, 'Measurements of atmospheric mercury species at a coastal site in the Antarctic and over the South Atlantic Ocean during polar summer', Environ. Sci. Technol. 37:22-31.

Thompson A.M. 1992, 'The Oxidizing Capacity of the Earth's Atmosphere: Probable Past and Future Changes', Science 256:1157-1165.

Wängeberg et al. 2008, 'Atmospheric mercury at Mediterranean coastal stations', Environmental Fluid Mechanics 8:101-116. 